\title{
Erratum to: The effectiveness of targeting never or rarely screened women in a national cervical cancer screening program for underserved women
}

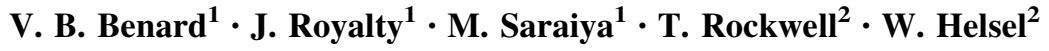

Published online: 7 May 2015

(C) Springer International Publishing Switzerland 2015

\section{Erratum to: Cancer Causes Control DOI 10.1007/s10552-015-0542-3}

In the original publication of the article, references 7 and 9 have not been cited properly. The corrected references are given below.

\section{References}

7. Tangka FKL, Howard D, Royalty J et al (2015) Cervical cancer screening of underserved women in the United States: results from the National Breast and Cervical Cancer Early Detection Program, 1997-2012. Cancer Causes Control. doi:10.1007/s10552-0150524-5
9. Watson M, Benard VB, Lin L, Rockwell T, Royalty J (2015) Provider management of equivocal cervical cancer screening results among underserved women, 2009-2011: follow-up of atypical squamous cells of undetermined significance. Cancer Causes Control. doi:10.1007/s10552-015-0549-9

The online version of the original article can be found under doi:10.1007/s10552-015-0542-3.

$\triangle$ V. B. Benard vdb9@cdc.gov

1 Division of Cancer Prevention and Control, National Center for Chronic Disease Prevention and Health Promotion, Centers for Disease Control and Prevention (CDC), 4770 Buford Highway NE, Mailstop F-76, Atlanta, GA 30341, USA

2 Information Management Services, Inc., 6110 Executive Blvd., Suite 310, Rockville, MD 20852, USA 